UDC 539.3

\title{
BUCKLING AND VIBRATIONS OF THE SHELL WITH THE HOLE UNDER THE ACTION OF THERMOMECHANICAL LOADS
}

\author{
V.A. Bazhenov, \\ Doctor of Technical Science \\ O.P. Krivenko, \\ Candidate of Science (Engineering) \\ Kyiv National University of Construction and Architecture \\ 31, Povitroflotsky ave., Kyiv, Ukraine, 03037
}

DOI: $10.32347 / 2410-2547.2020 .104 .136-146$

\begin{abstract}
The paper outlines the fundamentals of the method of solving static problems of geometrically nonlinear deformation, buckling, and vibrations of thin thermoelastic inhomogeneous shells with complex-shaped midsurface, geometrical features throughout the thickness, under complex thermomechanical loading. The technique is based on the geometrically nonlinear equations of three-dimensional thermoelasticity, the finite element formulation of the problem in increments, and the use of the moment finite-element scheme. A thin shell is considered by this method as a threedimensional body. We approximate a shell by one spatial universal finite element (FE) throughout the thickness. The universal FE is based on an isoparametric spatial FE with polylinear shape functions for coordinates and displacements. The universal element has additional variable parameters introduced to expand its capabilities. The method of modal analysis of the shell is based on an approach that at each current stage of thermomechanical loading takes into account the stresses accumulated at the previous stages. The developed algorithm allows one to study geometric nonlinear deformation and buckling of elastic shells of an inhomogeneous structure with a thin and medium thickness, as well as to study small vibrations of the shells relative to the reference deformed state caused by static loading, taking into account large displacements and a prestressed state. An analysis of the stability and vibration of the spherical panel with the hole is carried out. The effect on the frequencies and mode shapes of the shell of the sequential action of thermal and mechanical loads is investigated.
\end{abstract}

Keywords: elastic shell, hole, buckling, natural frequency, mode shapes, thermo-mechanical load, universal finite element.

\section{Introduction}

Shells as elements of thin-walled structures are widely used in various engineering applications such as construction, engineering, shipbuilding, aviation and space technology, transport and other branches.

The shells can be weakened by holes, channels, cavities, and dents in accordance with technological necessity. During operation such structures can be subjected to loads of various nature including mechanical and thermal. At the same time static loads significantly affect both the stress-strain state of the structure and the dynamic characteristics which include the frequencies and modes of natural vibrations.

Obtaining information about the natural frequencies and modes of the shell is one of the important aspects of the complex analysis of the thin-walled structure. This modal information plays a key role in the design of these

(C) Bazhenov V.A., Krivenko O.P. 
structures and can provide the strength of the elastic system even at the design stage.

There are a large number of theoretical, numerical and experimental studies of shells of various shapes. Background and bibliography can be found in Ref. [1-3, 915]. Although the basic equations and relations of the theory of shells were obtained long ago, until now analytical solutions to problems have been obtained only for some relatively simple classes of shells with predominantly canonical form. Therefore methods of numerical analysis are widely used to solve the problems of shell theory. Currently, there is a fairly large arsenal of these methods. On their basis effective approaches have been developed to solve a wide class of problems on the stress-strain state, stability and vibration of thin plates and shells. A large number of monographs are devoted to the presentation of these approaches [1-3, 7, 10, 12, 1421]. In general a broad bibliographic description is devoted to various aspects of shell researches [22]. This description has been compiled by David Bushnell since 2011 and is currently being updated. On this website page there are people who have made a significant contribution directly to the field of stability loss, as well as people who have laid the foundations of the theory and methods of researching various aspects of analysis for shell structures. The authors as researchers involved in the study of geometrically nonlinear deformation, stability, buckling, and oscillations of thin elastic shells [1-3] are also included in Shell Buckling People.

In recent decades the number of articles on the analysis of elastic shells has expanded significantly. Among them much attention is paid to analyzing elastic thin shells reinforced by ribs [1-3, 5,6,7,11, 23-25]. Much less research has been devoted to investigating shells with various weakening [1-8].

The article is a continuation of studies of deformation, buckling, and vibrations of shell structures. Research is devoted to modal analysis of a thin shell with a hole.

\section{Problem statement and research method}

The methodology for studying the natural vibrations of thin-walled shell structures, taking into account the effects of static thermo-mechanical loading, is based on an integrated approach. The finite element method [1-2] for investigating static problems of the stress-strain state, buckling, and postbuckling behavior of thin inhomogeneous shells, and the method $[3,26]$ for modal analysis of shells taking into account the pre-stressed state at each step of the thermo-mechanical load are used. Thus, the problem of determining the natural frequencies and vibration modes of the shell is solved by the incremental method in two stages.

At the first stage, the static problem of nonlinear deformation of inhomogeneous shells is solved by the method given in Ref. [1-2]. At this stage for the corresponding increments of the static load the parameters of the stressstrain state for the finite-element shell model (FESM) are determined. These parameters include: deformed shape (new coordinates of the nodes and increment of displacements for them), the stresses in the finite elements (FE), and others. This problem is solved for each increment of thermo-mechanical load. 
The method is based on the geometrically nonlinear equations of threedimensional thermoelasticity, the finite element formulation of the problem in increments, and the use of the moment finite-element scheme (MFES).

To develop the FESM, we approximate a thin shell by one spatial FE throughout the thickness. The universal FE is based on an isoparametric spatial FE with polylinear shape functions for coordinates and displacements. Additional variable parameters have been introduced to enhance the capabilities of this FE [1-2]. The nonlinear deformation of shells is analyzed using the incremental method based on the general Lagrangian formulation. The problem of nonlinear deformation, buckling, and post-buckling behavior of inhomogeneous shells is solved by a combined algorithm. The algorithm employs the parameter continuation method, and a modified NewtonKantorovich method at the step of the load's increment [1-2].

At the second stage of the current step, the thermo-mechanical load is assumed to be zero (i.e., "deleted") and the parameters of natural vibrations are determined $[3,26]$. At this stage we use the new shell shape and the pre-stressed state which has been determined at the first stage. For each load increment the natural frequencies and mode shapes are computed until a negative value of the fundamental tone (lowest frequency) appears. This is because of according to the dynamic criterion, the moment of the loading at which a negative value of the frequency appears may be taken as the moment of loss of stability of the shell and this load is adopted as critical [3, 26, 27].

The determination of the natural frequencies of the shell is not performed at the next steps of the thermo-mechanical load increment. Next, only the postbuckling behavior of the shell is investigated. The accuracy of the calculation for the natural vibrations of the shell taking into account the pre-stressed state is confirmed by the coincidence of the value of the upper critical load with that obtained in another way.

This approach allows us to analyze the joint effect of thermo-mechanical load parameters and the geometric characteristics of the shells on the buckling and natural vibrations of shell structures.

\section{Buckling and natural vibrations of a panel with a hole}

A shallow spherical panel of square planform hinged at the edges and having

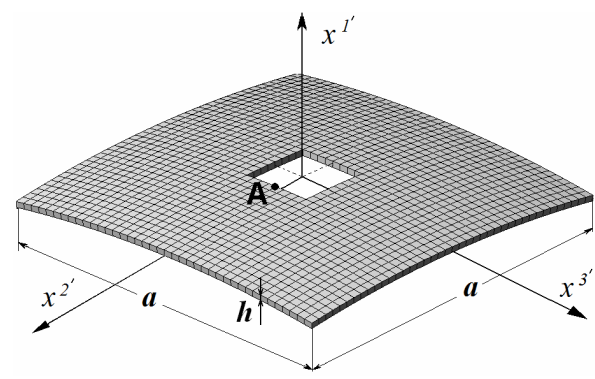

Fig. 1. A shallow spherical panel with a central hole a central square hole is considered (Fig. 1). The shell is under the action of thermo-mechanical loading.

Curvature of the panel is defined by the parameter $K=2 a^{2} /(R h)=32$, where: $h=1 \mathrm{~cm}$ is the thickness, $a=60 h$ is a size of the panel in the plan, $R=225 h$ is the radius of midsurface. The input data: width of the 
hole $b_{o}=12 h$, elastic modulus $E=2.1 \cdot 10^{6} \mathrm{~kg} / \mathrm{cm}^{2}$, Poisson's ratio $v=0.3$, linear expansion coefficient $\alpha=0.12 \cdot 10^{-4} \mathrm{deg}^{-1}, \rho=7.85 \cdot 10^{-3} \mathrm{~kg} / \mathrm{cm}^{3}$. The data are taken from Ref. [7, part. 2], where the problem of panel stability under the action of pressure alone is considered.

The effect of the thermo-mechanical load on the panel consists of two stages:

(i) the shell is gradually heated by the temperature field whose parameter increases from $0^{\circ} \mathrm{C}$ to a set value $T^{\circ} \mathrm{C}$. So, at the first stage the stress-strain state of the shell is perturbed by the temperature field;

(ii) the panel is subjected to uniform normal pressure of intensity $q$ in addition. So, at the second stage the temperature field is remaining constant.

We consider three options for preheating at $T=-20^{\circ}, 0^{\circ}, 20^{\circ} \mathrm{C}$. Results are presented in terms of dimensionless parameters: $\bar{q}=a^{4} q /\left(E h^{4}\right), \bar{u}^{1^{\prime}}=u^{1^{\prime}} / h$, where $u^{1^{\prime}}$ is the deflection of the panel along the axis $x^{1^{\prime}}$.

The results of investigations of the processes of geometrically nonlinear deformation and buckling of a smooth panel and a panel with a hole are details presented in in Ref. [1-2, 28].

Examination of the dependence of the frequencies and modes of natural vibrations of a smooth panel on the mechanical load is given in $[4,26]$. It is shown that neglecting the prestressed state (only the new deformed state of the shell was taken into account) leads to an incorrect determination of the upper critical load and frequencies.

The calculating results of a smooth panel are basic for analyzing the effect of geometric features such as holes on the natural vibrations of a shallow shell. There is the dashed line with the mark " - " for the solution of the smooth panel on the "load - deflection" (" $\bar{q}-\bar{u}$ ") and "load - frequency" (" $\bar{q}-\omega$ ") curves. The calculation results for a panel with a hole are marked "...".". For the panel without hole the deflection have been considered at its center, and for the panel with a hole the deflection have been considered at the point $A$ (Fig. 1). The design model is the panel with mesh $40 \times 40$ FEs.

The accuracy of calculations in the problems of buckling of the indicated panels had been determined by a comparative analysis of the solutions obtained using the MFES and calculations performed using the software LIRA [29] (Fig. 2, Fig. 3).

A comparison of the " $\bar{q}-\bar{u}$ " curves obtained by the MSFE and software LIRA for shells without hole $(\square)$ and with hole $(\boldsymbol{m})$ when their loading only pressure $\left(T=0^{\circ} \mathrm{C}\right)$ reveals agreement between the " $\bar{q}-\bar{u}$ " curves in the prebuckling domain and when loss of stability. The difference between the values of $\bar{q}_{\mathrm{cr}}^{\text {up }}$ is respectively $-1.9 \%$ and $2.9 \%$ (Fig. 2). 


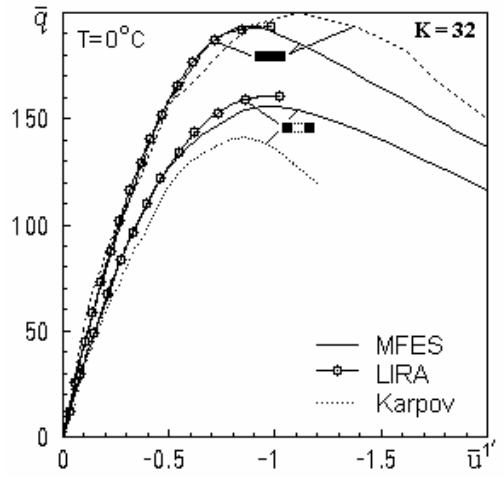

Fig. 2

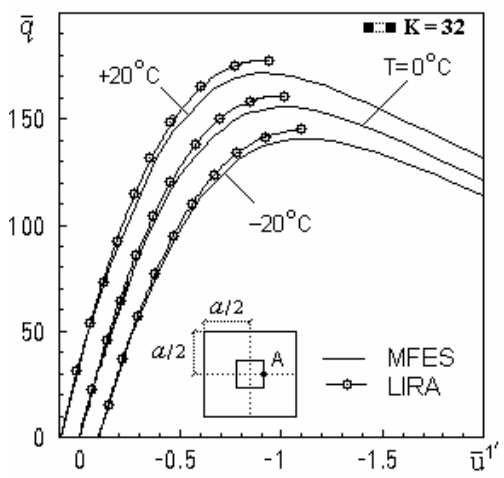

Fig. 3

For all heating cases, both solutions are in good agreement with each other throughout the " $\bar{q}-\bar{u}$ " curve (Fig. 3). The disagreement between the values of $\bar{q}_{\mathrm{cr}}^{\mathrm{up}}$ is an area $3.0-3.5 \%$. Configurations for the deformed shell after pre-cooling to $T=-20^{\circ} \mathrm{C}$ and preheating to $T=+20^{\circ} \mathrm{C}$ obtained by both methods, are in complete agreement with each other and have little difference from the original form $\left(T=0^{\circ} \mathrm{C}, \bar{q}=0\right)$. Forms of buckling are in good agreement too (Fig. 4 (a)). Buckling of the panel occurs with click of its central part (Fig. 4 (b)).

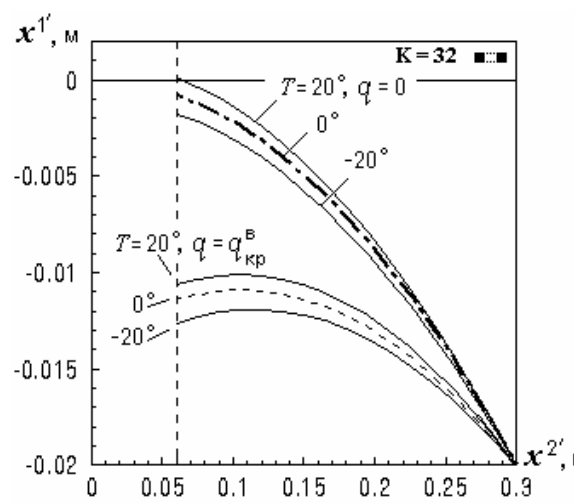

(a)

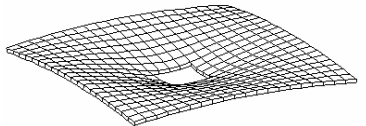

(b)

Fig. 4
We have found that that weakening of the smooth panel (" ") by the central hole ("口...") reduces the critical load $\bar{q}_{\mathrm{cr}}^{\text {up }}$ by $19.2 \%$ (Fig. 2). For the shell with the hole ("ח-.."), pre-cooling and preheating leads to a change in the critical load $\bar{q}_{\mathrm{cr}}^{\text {up }}$ by 9.78 and $-9.97 \%$ compared to the corresponding unheated panel ( $\left.T=0^{\circ} \mathrm{C}\right)$ (Fig. 3).

An analysis of the natural vibrations of the smooth ("ש") and weakened ("m.") panel shows that for unloaded shells $\left(T=0^{\circ} \mathrm{C}, \bar{q}=0\right)$ the presence of a hole reduces the frequency $\omega_{1}$ by $3.3 \%$ (Table 1 ). At the same time, frequencies $\omega_{1}$ and $\omega_{2}$ are double for a shell without a 
hole, and frequencies $\omega_{2}$ and $\omega_{3}$ are double for a panel with a hole. Therefore, the mode shapes differ for the respective shells. For the smooth panel, the mode shapes that correspond to double frequencies $\omega_{1}$ and $\omega_{2}$ are conjugate, and the mode that corresponds to the frequency $\omega_{3}$ is characterized by the oscillation of the central part of the shell (Fig. 5). The opposite nature of the mode shapes is observed for a panel with a hole (Fig. 6). Modes transform in accordance with the change in the number of double frequencies during loading (Table 1). At buckling domain, the vibration modes have the same shape for the shell without a hole (Fig. 5 (c)) and with it (Fig. 6 (a)).

Table 1

Panel natural frequencies $\omega_{i}$ at various load values $\bar{q}^{i}\left(T=0^{\circ} \mathrm{C}\right)$

\begin{tabular}{|c|c|c|c|c|c|c|}
\hline $\begin{array}{c}\text { № } \\
\bar{q}^{i}\end{array}$ & $\omega_{1}, \mathrm{~Hz}$ & $\omega_{2}, \mathrm{~Hz}$ & $\omega_{3}, \mathrm{~Hz}$ & $\omega_{4}, \mathrm{~Hz}$ & $\omega_{5}, \mathrm{~Hz}$ & $\omega_{6}, \mathrm{~Hz}$ \\
\hline 0 & $.53378 \mathrm{e}+3$ & $.53378 \mathrm{e}+3$ & $.54740 \mathrm{e}+3$ & $.69124 \mathrm{e}+3$ & $.79609 \mathrm{e}+3$ & $.81664 \mathrm{e}+3$ \\
\hline 0 & $.51604 \mathrm{e}+3$ & $.51938 \mathrm{e}+3$ & $.51938 \mathrm{e}+3$ & $.60926 \mathrm{e}+3$ & $.71434 \mathrm{e}+3$ & $.81960 \mathrm{e}+3$ \\
\hline $\mathbf{- 1}$ & $.51213 \mathrm{e}+3$ & $.51251 \mathrm{e}+3$ & $.51251 \mathrm{e}+3$ & $.59917 \mathrm{e}+3$ & $.70329 \mathrm{e}+3$ & $.81049 \mathrm{e}+3$ \\
\hline 2 & $.49805 \mathrm{e}+3$ & $.49805 \mathrm{e}+3$ & $.50057 \mathrm{e}+3$ & $.58103 \mathrm{e}+3$ & $.68530 \mathrm{e}+3$ & $.79348 \mathrm{e}+3$ \\
\hline 3 & $.47453 \mathrm{e}+3$ & $.47453 \mathrm{e}+3$ & $.48176 \mathrm{e}+3$ & $.55137 \mathrm{e}+3$ & $.65603 \mathrm{e}+3$ & $.76620 \mathrm{e}+3$ \\
\hline 4 & $.43368 \mathrm{e}+3$ & $.43368 \mathrm{e}+3$ & $.44905 \mathrm{e}+3$ & $.49943 \mathrm{e}+3$ & $.60537 \mathrm{e}+3$ & $.72019 \mathrm{e}+3$ \\
\hline 5 & $.34814 \mathrm{e}+3$ & $.34814 \mathrm{e}+3$ & $.37947 \mathrm{e}+3$ & $.38773 \mathrm{e}+3$ & $.49978 \mathrm{e}+3$ & $.63141 \mathrm{e}+3$ \\
\hline 6 & $.27518 \mathrm{e}+3$ & $.27518 \mathrm{e}+3$ & $.29254 \mathrm{e}+3$ & $.33249 \mathrm{e}+3$ & $.45578 \mathrm{e}+3$ & $.58481 \mathrm{e}+3$ \\
\hline 7 & $.24566 \mathrm{e}+3$ & $.24566 \mathrm{e}+3$ & $.25091 \mathrm{e}+3$ & $.31914 \mathrm{e}+3$ & $.44342 \mathrm{e}+3$ & $.57459 \mathrm{e}+3$ \\
\hline 8 & $.18104 \mathrm{e}+3$ & $.19133 \mathrm{e}+3$ & $.19133 \mathrm{e}+3$ & $.28532 \mathrm{e}+3$ & $.41071 \mathrm{e}+3$ & $.55581 \mathrm{e}+3$ \\
\hline 9 & $.14446 \mathrm{e}+3$ & $.16503 \mathrm{e}+3$ & $.16503 \mathrm{e}+3$ & $.27148 \mathrm{e}+3$ & $.39684 \mathrm{e}+3$ & $.54946 \mathrm{e}+3$ \\
\hline 10 & $.85034 \mathrm{e}+2$ & $.13249 \mathrm{e}+3$ & $.13251 \mathrm{e}+3$ & $.26427 \mathrm{e}+3$ & $.38724 \mathrm{e}+3$ & $.54844 \mathrm{e}+3$ \\
\hline 11 & $-.31833 \mathrm{e}+5$ & $.93008 \mathrm{e}+2$ & $.93082 \mathrm{e}+2$ & $.26060 \mathrm{e}+3$ & $.37989 \mathrm{e}+3$ & $.55059 \mathrm{e}+3$ \\
\hline
\end{tabular}

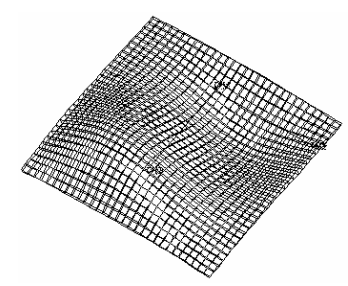

(a)

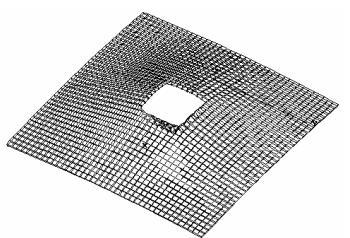

(a)

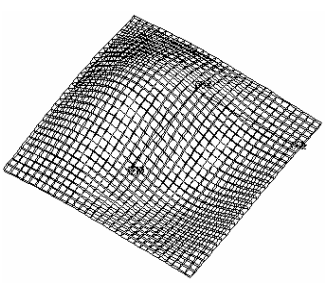

(b)

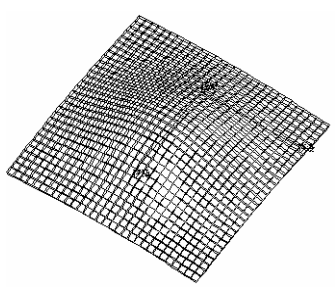

(c)

Fig. 5

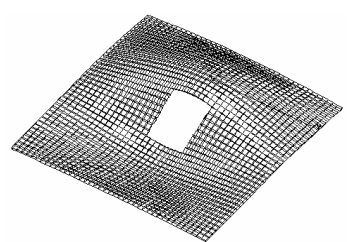

(b)

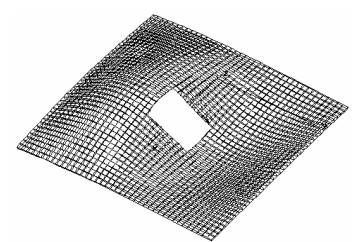

(c)

Fig. 6 


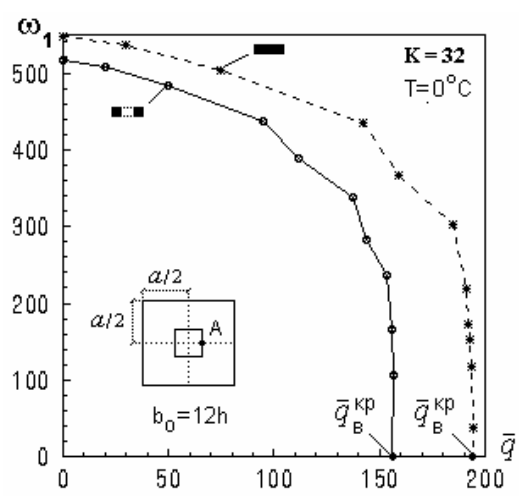

Fig. 7

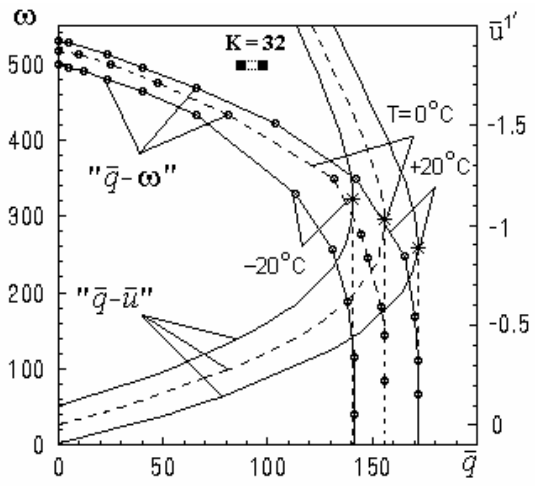

Fig. 8

The " $\bar{q}-\omega_{1}$ " curves have the same fashion for the investigated shells when only pressure is acting $\begin{array}{lll}\left(T=0^{\circ} \mathrm{C}\right) \quad \text { (Fig. 7). The load } & \end{array}$ moments at which the natural vibrations have been calculated are shown in the figure. These moments correspond to the load $\bar{q}^{i} \quad(i=\overline{1,11})$ (Table 1). The applied pressure causes a restructuring of both frequency multiplicity and vibration modes. The frequencies $\omega_{2}$ and $\omega_{3}$ become double when $i \geq 8$. Accordingly, the mode shape for the frequency $\omega_{1}$ becomes the simplest (Fig. 6 (a)).

Preheating and pre-cooling of the shell leads to small changes in the frequencies (Table 2). In the case of pre-cooling by $T=-20^{\circ} \mathrm{C}$, the mode shapes are similar to ones shown in Fig. 6. In the case of preheating by $T=+20^{\circ} \mathrm{C}$, the mode shapes are similar to the (b), (c), (a) shapes of Fig. 6.

The " $\bar{q}-\omega_{1}$ " curves have the same fashion for the investigated shell in all cases of heating (Fig. 8). At buckling domain, the mode shape is similar to the shape from Fig. 6 (a) for all cases of heating.

Table 2

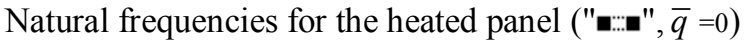

\begin{tabular}{|c|c|c|c|c|c|}
\hline$T^{\circ} \mathrm{C}$ & $\omega_{1}$ & $\omega_{2}$ & $\omega_{3}$ & $\omega_{4}$ & $\omega_{5}$ \\
\hline 0 & $.51604 \mathrm{e}+3$ & $.51938 \mathrm{e}+3$ & $.51938 \mathrm{e}+3$ & $.60926 \mathrm{e}+3$ & $.71434 \mathrm{e}+3$ \\
\hline+20 & $.53017 \mathrm{e}+3$ & $.53028 \mathrm{e}+3$ & $.53151 \mathrm{e}+3$ & $.61665 \mathrm{e}+3$ & $.71662 \mathrm{e}+3$ \\
\hline$\Delta_{0}^{+20}$ & +2.37 & +2.10 & +2.33 & +1.21 & +0.32 \\
\hline-20 & $.49977 \mathrm{e}+3$ & $.50829 \mathrm{e}+3$ & $.50838 \mathrm{e}+3$ & $.60211 \mathrm{e}+3$ & $.71205 \mathrm{e}+3$ \\
\hline$\Delta_{0}^{-20}$ & -3.15 & -2.13 & -2.12 & -1.17 & -0.32 \\
\hline
\end{tabular}




\section{Conclusions}

The finite element approach for determining the natural vibrations of shells of an inhomogeneous structure is developed on the basis of a modified isoparametric spatial finite element with polylinear shape functions. The algorithm for modal analysis of the shells is based on the finite element method for studying shells with geometric features throughout thickness. The prestressed state of the deformed shell is taken into account at each stage of thermo-mechanical loading.

An analysis of the stability and vibration of the spherical panel with the hole is carried out. The effect on the frequencies and mode shapes of the shell of the sequential action of temperature and pressure is investigated. We have shown that the developed method is an effective tool for a comprehensive study of the stability and vibrations of inhomogeneous shells of thin and medium thickness under the action of thermo-mechanical loads.

\section{REFERENCES}

1. Bazhenov V.A., Krivenko O.P., Solovey M.O. Neliniyne deformuvannya ta stiykist pruzhnih obolonok neodnoridnoyi strukturi. - K.: ZAT «Vipol», 2010. - 316 s. [Nonlinear deformation and stability of elastic shells with inhomogenous structure. Kyiv: CJSC "VIPOL", 2010. 316s.] (ukr).

2. Bazhenov V.A., Krivenko O.P., Solovey N.A. Nelineynoe deformirovanie i ustoychivost uprugih obolochek neodnorodnoy strukturyi: Modeli, metodyi, algoritmyi, maloizuchennyie i novyie zadachi. - M.: Knizhnyiy dom «LIBROKOM», 2013. - 336 s. [Nonlinear deformation and stability of elastic shells of inhomogeneous structure: Models, methods, algorithms, poorlystudied and new problems. - Moscow: publishing house "LIBROKOM", 2013. - 336 s.] (rus)

3. Bazhenov $V$., Krivenko $O$. Buckling and Natural Vibrations of Thin Elastic Inhomogeneous Shells. - LAP LAMBERT Academic Publishing. Saarbruken, Deutscland, 2018. - 97 p.

4. Solovey N.A., Krivenko O.P., Malygina O.A. Konechnoelementnye modeli issledovaniya nelinejnogo deformirovaniya obolochek stupenchato-peremennoj tolshiny $\mathrm{s}$ otverstiyami, kanalami i vyemkami // Inzhenerno-stroitelnyj zhurnal (S.-Peterburg), 2015. - № 1. - S. 56-69. [Finite element models for the analysis of nonlinear deformation of shells stepwise-variable thickness with holes, channels and cavities // Magazine of Civil Engineering, 2015. - No. 1. Pp. 56-69.] (rus).

5. Gavrilenko G.D. Stability and load-bearing capacity of smooth and ribbed shells with local dents // International Applied Mechanics, 2004 - Vol. 40, No. 9. - Pp. 970-993.

6. Gavrilenko G.D., Matsner V.I., Kutenkova O.A. Dent and thickness effects on the critical loads of stiffened shells // Strength of Materials, 2011. - Vol. 43, No. 3. - Pp. 347-351.

7. Karpov V.V. Prochnost i ustojchivost podkreplennyh obolochek vrasheniya. V 2-h ch.: Ch.1. Modeli i algoritmy issledovaniya prochnosti i ustojchivosti podkreplennyh obolochek vrasheniya. FIZMATLIT, 2010. - 288 s.; Ch.2. Vychislitelnyj eksperiment pri staticheskom mehanicheskom vozdejstvii. - M.: FIZMATLIT, 2011. - 248 s. [Strength and buckling of reinforced shells of rotation. In 2 parts. Part 1 . Models and algorithms for investigating the strength and stability of reinforced shells of revolution. - FIZMATLIT (Moscow), 2010. - 288 p.; Part 2. Computational experiment with static mechanical action. - FIZMATLIT (Moscow), 2011. -248 p.] (rus).

8. Ghanbari Ghazijahani T., Showkati $H$. Locally imperfect conical shells under uniform external pressure // Strength of Materials (2013). No. 3. - Pp. 369-377.

9. Guz'A.N., Chernyshenko I.S., Chekhov Val.N., et al. Investigations in the theory of thin shells with openings (review) (1979). - Vol.15, No. 4. - Pp. 1015-1043.

10. Gavrilenko G.D., Macner V.I. Analiticheskij metod opredeleniya verhnih i nizhnih kriticheskih nagruzok dlya uprugih podkreplennyh obolochek. - Dnepropetrovsk: TOV «Barviks», 2007. - 
187 s. [An analytical method of determining the upper and lower critical loads for elastic reinforced shells] (rus).

11. Zarutskii V.A., Lugovoi P.Z., Meish V.F. Dynamic problems for and stress-strain state of inhomogeneous shell structures under stationary and nonstationary loads // International Applied Mechanics, 2009. - Vol 45, No 3. - Pp. 245-271.

12. Chapelle D., Bathe K.J. The finite element analysis of shells - Fundamentals. Series: Computational fluid and solid mechanics. - Berlin; Heidelberg: Springer, 2011. $-410 \mathrm{p}$.

13. Farbod Alijani, Marco Amabili. Non-linear vibrations of shells: A literature review from 2003 to 2013. International Journal of Non-Linear Mechanics, vol. 58, pp. 233-257 (2014).

14. Reddy J.N. Theory and Analysis of Elastic Plates and Shells, Second Edition - CRC Press, 2006. $-568 \mathrm{p}$.

15. Sumirin S., Nuroji N., and Besar S. Snap-Through Buckling Problem of Spherical Shell Structure // International Journal of Science and Engineering, 2015. - Vol. 8(1), - 54-59.

16. Metody rascheta obolochek. T. 4. Teoriya obolochek peremennoj zhestkosti / Grigorenko Ya.M., Vasilenko A.E. - K.: Nauk. dumka, 1981. - 544 s. [Methods for calculating shells. T. 4. The theory of shells of variable stiffness] (rus).

17. Metod konechnyh elementov v mehanike tverdyh tel / A.S.Saharov, V.N.Kislookij, V.V.Kirichevskij $i d r$. - K.: Visha shk. Golovnoe izd-vo, 1982. - 480 s. [The finite element method in mechanics] (rus).

18. Golovanov A.I., Tyuleneva O.N., Shigabutdinov A.F. Metod konechnyh elementov v statike i dinamike tonkostennyh konstrukcij. - M.: FIZMATLIT, 2006. - 392 s. [The finite element method in the statics and dynamics of thin-walled structures] (rus).

19. Valishvili N.V. Metody rascheta obolochek vrasheniya na ECVM. - M.: Mashinostroenie, 1976. - 278 s. [Methods for calculating shells of rotation on electronic digital computers] (rus.).

20. Oden J.T. Finite Elements of Nonlinear Continua, McGraw-Hill, New York (1971).

21. Zienkiewicz O.C. The Finite-Element Method in Engineering Science, McGraw-Hill, New York (1971).

22. David Bushnell and William D. Bushnell (http://shellbuckling.com).

23. Krivenko O.P. Effect of static loads on the natural vibrations of ribbed shells // Opir materialiv i teoriya sporud: nauk.-teh. zbirn. - K.: KNUBA, 2018. - Vip. 101. - S. 38-44 [Strength of Materials and Theory of Structures: Scientific-and-technical collected].

24. Amiro I.Ya., Zaruckij V.A., Polyakov P.S. Rebristye cilindricheskie obolochki. - K.: Naukova dumka, 1973. - 248 s. [Ribbed cylindrical shells] (rus).

25. Gavrilenko G.D., Macner V.I. Analiticheskij metod opredeleniya verhnih i nizhnih kriticheskih nagruzok dlya uprugih podkreplennyh obolochek. - Dnepropetrovsk: TOV «Barviks», 2007. 187 s. [An analytical method for determining the upper and lower critical loads for elastic reinforced shells] (rus).

26. Bazhenov V.A., Krivenko O.P., Legostayev A.D. Stijkist i vlasni kolivannya neodnoridnih obolonok z urahuvannyam napruzhenogo stanu // Opir materialiv i teoriya sporud: nauk.-teh. zbirn. - K.: KNUBA, 2015. - Vip. 95. - C. 96-113. [Stability and natural vibrations of inhomogeneous shells, taking into account the stress state] (ukr).

27. Vol'mir A.S. Nelinejnaya dinamika plastinok i obolochek. - M.: Nauka, 1972. - 432 s. [Nonlinear dynamics of plates and shells] (rus).

28. Bazhenov V.A., Solovei N.A., Krivenko O.P., Mishenko O.A. Modelirovanie nelinejnogo deformirovaniya i poteri ustojchivosti uprugih neodnorodnyh obolochek // Stroitelnaya mehanika inzhenernyh konstrukcij i sooruzhenij (MOSKVA), 2014. - № 5. - S. 14-33. [Modeling of nonlinear deformation and buckling of elastic inhomogeneous shells] (rus).

29. LIRA 9.4 Rukovodstvo polzovatelya. Osnovy. Uchebnoe posobie. / Strelec-Streleckij E.B., Bogovis V.E., Genzerskij Yu.V., Gerajmovich Yu.D. i dr. - K.: izd-vo «Fakt», 2008. - 164 s. [LIRA 9.4 User Guide. Basics. Textbook.] (rus). 


\section{Баженов В.А., Кривенко О.П.}

\section{ВТРАТА СТІЙКОСТІ ТА КОЛИВАННЯ ОБОЛОНКИ 3 ОТВОРОМ ПІД ДІЕЮ ТЕРМОСИЛОВОГО НАВАНТАЖЕННЯ}

У статті викладені основи методу розв'язання статичних задач геометрично нелінійного деформування, втрати стійкості та коливань тонких термопружних неоднорідних оболонок зі складною формою середньої поверхні, з геометричними особливостями за товщиною, в умовах дії складного термомеханічного навантаження. Метод заснований на геометрично нелінійних співвідношеннях тривимірної термопружності, скінченно-елементному формулюванні задачі в приростах і використанні моментної схеми скінченних елементів. За цим методом тонка оболонка розглядається як тривимірне тіло, яке моделюється по товщині одним універсальним просторовим скінченним елементом (СЕ). Універсальний СЕ розроблений на основі ізопараметричного просторового СЕ 3 полілінійними функціями форми для координат і переміщень. Можливості модифікованого елемента розширені за рахунок введення додаткових змінних параметрів. Методика модального аналізу неоднорідних оболонок базується на підході, за яким на кожному кроці термосилового навантаження враховуються накопичені на попередніх кроках напруження. Розроблена методика дозволяє комплексно досліджувати геометрично нелінійне деформування та стійкість тонких і середньої товщини пружних оболонок неоднорідної структури та вивчати малі коливання оболонки відносно відлікового деформованого стану, що викликаний довільним статичним навантаженням, 3 урахуванням великих переміщень $\mathrm{i}$ переднапруженого стану. Виконано аналіз стійкості та коливань сферичної панелі з отвором. Досліджено вплив послідовної дії теплових і силових навантажень на частоти і форми коливань оболонки.

Ключові слова: пружна оболонка, отвір, втрата стійкості, власна частота, форма коливань, термосилове навантаження, універсальний скінченний елемент.

\section{Баженов В.А., Кривенко О.П.}

\section{ПОТЕРЯ УСТОЙЧИВОСТИ И КОЛЕБАНИЯ ОБОЛОЧКИ С ОТВЕРСТИЕМ ПОД ДЕЙСТВИЕМ ТЕРМОСИЛОВОЙ НАГРУЗКИ}

В статье изложены основы метода решения статических задач геометрически нелинейного деформирования, потери устойчивости и колебаний тонких термоупругих неоднородных оболочек со сложной формой срединной поверхности, с геометрическими особенностями по толщине, в условиях действия сложной термомеханической нагрузки. Метод основан на геометрически нелинейных соотношениях трехмерной термоупругости, конечно-элементной формулировке задачи в приращениях и использовании моментной схемы конечных элементов. Тонкая переменной толщины оболочка сложной геометрической формы рассматривается согласно методу как трехмерное тело, которое моделируется по толщине одним универсальным пространственным конечным элементом (КЭ). Универсальный КЭ разработан на основе изопараметрического пространственного КЭ с полилинейными функциями формы для координат и перемещений. Возможности модифицированного элемента расширены за счет введения дополнительных переменных параметров. Методика модального анализа оболочки базируется на подходе, когда на каждом шаге термосилового нагружения учитываются напряжения, накопленные на предыдущих шагах. Разработанная методика позволяет комплексно исследовать геометрически нелинейное деформирование и устойчивость тонких и средней толщины упругих оболочек неоднородной структуры, а также изучать малые колебания оболочек относительно отсчетного деформированного состояния, вызванного произвольной статической нагрузкой, с учетом больших перемещений и преднапряженного состояния. Выполнен анализ устойчивости и колебаний сферической панели с отверстием. Исследовано влияние последовательного воздействия тепловых и силовых нагрузок на частоты и формы колебаний оболочки.

Ключевые слова: упругая оболочка, отверстие, потеря устойчивости, собственная частота, форма колебаний, термосиловая нагрузка, универсальный конечный элемент. 


\section{УДК 539.3}

Баженов В.А., Кривенко О.П. Втрата стійкості та коливання оболонки з отвором під дією термосилового навантаження // Опір матеріалів і теорія споруд: наук.-тех. збірник - К.: КНУБА, 2020. - Вип. 104. - С. 136-146. - Англ.

Досліджено вплив послідовної дї̈ нагріву та тиску на стійкість і коливань сферичної панелі з отвором.

Табл. 2. Ил. 8. Библиогр. 29 назв.

\section{UDC 539.3}

Bazhenov V.A., Krivenko O.P. Buckling and vibrations of the shell with the hole under the action of thermomechanical loads // Strength of Materials and Theory of Structures: Scientificand-technical collected articles. - K.: KNUBA, 2020. - Issue 104. - P. 136-146.

Effect of the sequential action of heating and pressure on the stability and vibration of a spherical panel with a hole is investigated.

Tabl. 2. Fig. 8. Bibliograf. 29 ref.

Баженов В.А., Кривенко О.П. Потеря устойчивости и колебания оболочки с отверстием под действием термосиловой нагрузки // Сопротивление материалов и теория сооружений: науч.-тех. сборн. - К.: КНУБА, 2020. - Вып. 104. - С. 136-146. - Англ.

Исследовано влияние последовательного воздействия нагрева и давления на устойчивость и колебаний сферической панели с отверстием.

Табл. 2. Ил. 8. Библиогр. 29 назв.

Автор (вчена ступень, вчене звання, посада): доктор технічних наук, професор, академік Національної академії педагогічних наук України, директор НДІ будівельної механіки БАЖЕНОВ Віктор Андрійович

Адреса робоча: 03680 Украӥна, м. Київ, Повітрофлотський проспект 31, Киӥвський наиіональний університет будівництва і архітектури.

Робочий тел.: +38(044) 245-48-29.

мобільний тел.: +38(067)111-22-33

E-mail: Bazhenov.va@knuba.edu.ua

ORCID ID: https//orcid/org/0000-0002-5802-9848

Автор (вчена ступень, вчене звання, посада): кандидат технічних наук, стариий науковий співробітник, провідний науковий співробітник НДІ будівельної механіки КНУБА КРИВЕНКО Ольга Петрівна

Адреса робоча: 03680 Украӥна, м. Київ, Повітрофлотський проспект 31, Київський наиіональний університет будівництва і архітектури.

Робочий тел.: +38(044) 245-48-29.

мобільний тел.: +38(066) 048-32-77

E-mail: Kryvenko.op@knuba.edu.ua

ORCID ID: https//orcid/org/0000-0002-1623-9679 